\title{
Browse potential of bristly locust, smooth sumac, and sericea lespedeza for small ruminants
}

\author{
M. Acharya $(1)$ - A. J. Ashworth • D. M. Burner · J. M. Burke • D. H. Pote • \\ J. P. Muir
}

Received: 7 June 2018/Accepted: 16 December 2019/Published online: 27 December 2019

(C) The Author(s) 2019

\begin{abstract}
Temperate grass and legume yield and quality are markedly reduced during hot, dry summer months in the southern USA; therefore, browse species could add feed options for small ruminants during this season. Our objective was to compare total biomass yield and forage nutritive value of two browse species, leguminous bristly locust (Robinia hispida) and smooth sumac (Rhus glabra), as well as a leguminous shrub known as sericea lespedeza (Lespedeza cuneate), during summer months (June, July, August and September). Plants were sampled monthly during growing-seasons in 2012 and 2013 to determine biomass yield (foliar, shoot, and total above ground) and foliar nutritive value [crude protein (CP), acid detergent fiber (ADF), acid detergent lignin
\end{abstract}

M. Acharya ( $\square)$

Department of Poultry Science, University of Arkansas, 1260 W. Maple St., Fayetteville, AR 72701, USA

e-mail:macharya@uark.edu

A. J. Ashworth

USDA-ARS, Poultry Production and Product Safety

Research Unit, 1260 W. Maple St., Fayetteville,

AR 72701, USA

D. M. Burner - J. M. Burke - D. H. Pote

USDA-ARS, Dale Bumpers Small Farms Research

Center, 6883 South State Highway 23, Booneville,

AR 72927, USA

J. P. Muir

Texas A \& M AgriLife Research, 1229 N US Hwy 281,

Stephenville, TX 76401, USA
(ADL), and condensed tannins (CT)]. There was a species $\times$ harvest time interaction for foliar biomass yield $(P=0.0125)$. This interaction was likely due to low yield in June for bristly locust compared with sericea lespedeza and smooth sumac, but in all other months (July, August, and September) yields were similar for each species. Bristly locust had the highest CP (16.9\%), followed by sericea lespedeza (14.8\%), and smooth sumac (12.3\%). Acid detergent fiber and ADL were similar between bristly locust (ADF 38.5\%; ADL 24.1\%) and sericea lespedeza (ADF 38.4\%; ADL 23.1\%), but was lower for smooth sumac (ADF $22.1 \%$, ADL $6.3 \% ; P<0.05)$. Condensed tannins, an anti-nutritive yet anti-parasitic phenolic compounds, were highest in smooth sumac, intermediate in bristly locust, and lowest in sericea lespedeza. Plant foliar percentage (ratio of foliar to shoot mass), was highest in smooth sumac $(55.1 \%)$, followed by sericea lespedeza (47.7\%), and bristly locust (42.6\%). Overall, smooth sumac had the highest foliar biomass and lowest ADF and ADL; however, this species had the lowest CP and highest CT. Consequently, average foliar biomass yield of all three browse species in our study far exceeded forage yield from dominant forage species [tall fescue (Schedonorus arundinaceus) and bermudagrass (Cyanodon dactylon)] in this region and may provide high-yielding, low input, anti-parasitic fodder for small ruminants during this period in the Southeastern U.S. 
Keywords Bristly locust - Sericea lespedeza .

Smooth sumac $\cdot$ Browse species $\cdot$ Small ruminants

\section{Introduction}

The southeastern U.S. has hot and dry weather during July and August (lowest rainfall and highest temperature; NOAA 2010), which causes marked reductions in forage yield from predominant grass species such as tall fescue (Schedonorus arundinaceus) and bermudagrass (Cyanodon dactylon; Ball et al. 2015). Alternative forage production systems are needed to feed small ruminants during summer. A browse-based pasture system would be preferred to a grass-based pasture system for goats because browse accommodates their natural grazing behavior and allows them to avoid gastrointestinal nematodes (Terrill et al. 2012). Furthermore, tree legumes are mostly deep-rooted, drought tolerant, $\mathrm{N}$-fixing, and may provide highquality, protein-rich forage to livestock (Adams et al. 2010). Thus, leguminous trees may be a reasonable forage alternative for browsers during hot and dry summer months (Burner et al. 2005).

Bristly locust is a leguminous tree native to the southeastern U.S. (Fernald 1950). This species can be established on moderately acidic soil ( $\mathrm{pH}$ 5.6) with $\mathrm{P}$, $\mathrm{Ca}, \mathrm{K}$ and $\mathrm{Mg}$ concentration of 90, 370, 2330, and $280 \mathrm{~kg} \mathrm{ha}^{-1}$, respectively (Burner and Burke 2012). In addition, mature bristly locust trees can tolerate a wide range of $\mathrm{pH}$ and are drought tolerant (Fernald 1950; Molz and Browning 1977; Hensley and Carpenter 1986; Burner and Burke 2012). This species grows as a shrub or small tree and has pinnately compound leaves (Burner and Burke 2012). Goats (Capra hircus L.) readily browse tree species and producers in southeastern Arkansas have been observed to graze sheep (Ovis aries L.) in bristly locust silvopasture without any negative health issue.

Sericea lespedeza, is a warm season forage legume with moderate protein, good digestibility and rich in CT (Mechineni et al. 2014). Height of the mature plant ranges from 0.5 to $2 \mathrm{~m}$ and have shrubby appearance due to multiple stems. Leaflets are $0.5-2.5 \mathrm{~cm}$ long and $6 \mathrm{~mm}$ wide, and leaves are densely distributed on branches and main stem (Sidhu 2010). In addition, sericea lespedeza is a preferred summer forage for goats and sheep (Min et al. 2004).
Smooth sumac is a common browse species in the southern U.S. that can be established in low input soils (limited or no external input of fertilizer and pesticide), is drought tolerant, and has a high leaf $\mathrm{CP}$ (Rayne and Mazza 2007; Karki 2013). The plant grows as a shrub or small tree, and has pinnately compound leaves each with 20-30 leaflets that grow up to $0.5 \mathrm{~m}$ long with a fern like appearance. Smooth sumac foliage was reported to contain moderate protein, good digestibility and energy, and up to 35\% tannins (Clarke et al. 1949; Hart 2013).

The objective of this study was to determine total biomass yield and foliar nutritive value of two woody leguminous forages and an herbaceous legume during the summer period to determine their potential for small ruminant feeding in silvopastoral systems.

\section{Materials and methods}

Site description

This study was conducted at the USDA-ARS Dale Bumpers Small Farms Research Unit in Booneville, Arkansas, U.S. $\left(35^{\circ} 08^{\prime} \mathrm{N}, 93^{\circ} 98^{\prime} \mathrm{W}\right)$. Soil type in the experimental site was Leadvale silt loam (Fine-silty, siliceous, semiactive, thermic Typic Fragiudults), with water movement and plant rooting limited by a fragipan at a depth of 14-97 cm. During late winter and early spring, the fragipan layer severely restricts water movement in the soil profile, and a perched water table is common at a depth of 61-91 cm (NRCS 2003). The site received $990 \mathrm{~mm}$ rainfall in 2012 and $1350 \mathrm{~mm}$ in 2013. The 30 year mean annual precipitation during the same period was $1270 \mathrm{~mm}$ with the lowest precipitation during July and August (NOAA 2010; Fig. 1A). Mean annual temperatures in 2012 and 2013 were 18.2 and $15.6{ }^{\circ} \mathrm{C}$, respectively. The 30 year (1981-2010) mean annual temperature was $15.5^{\circ} \mathrm{C}$, with winter minimum of $10.6{ }^{\circ} \mathrm{C}$ and summer maximum of $32.3{ }^{\circ} \mathrm{C}$ (NOAA 2010, Fig. 1B).

\section{Plot establishment}

Dormant bristly locust and smooth sumac trees growing in a similar soil type about $1.5 \mathrm{~km}$ from the research site were removed with roots remaining intact and then transplanted to the experimental plots at a depth of $15 \mathrm{~cm}$ in March 2011. Trees 1-2-m tall and 
Fig. 1 A Total monthly precipitation and $\mathbf{B}$ mean monthly temperature in Booneville, Arkansas, USA in 2012 and 2013. Thirtyyear average of total monthly precipitation and temperature (1981-2010) were obtained from NOAA (2010)
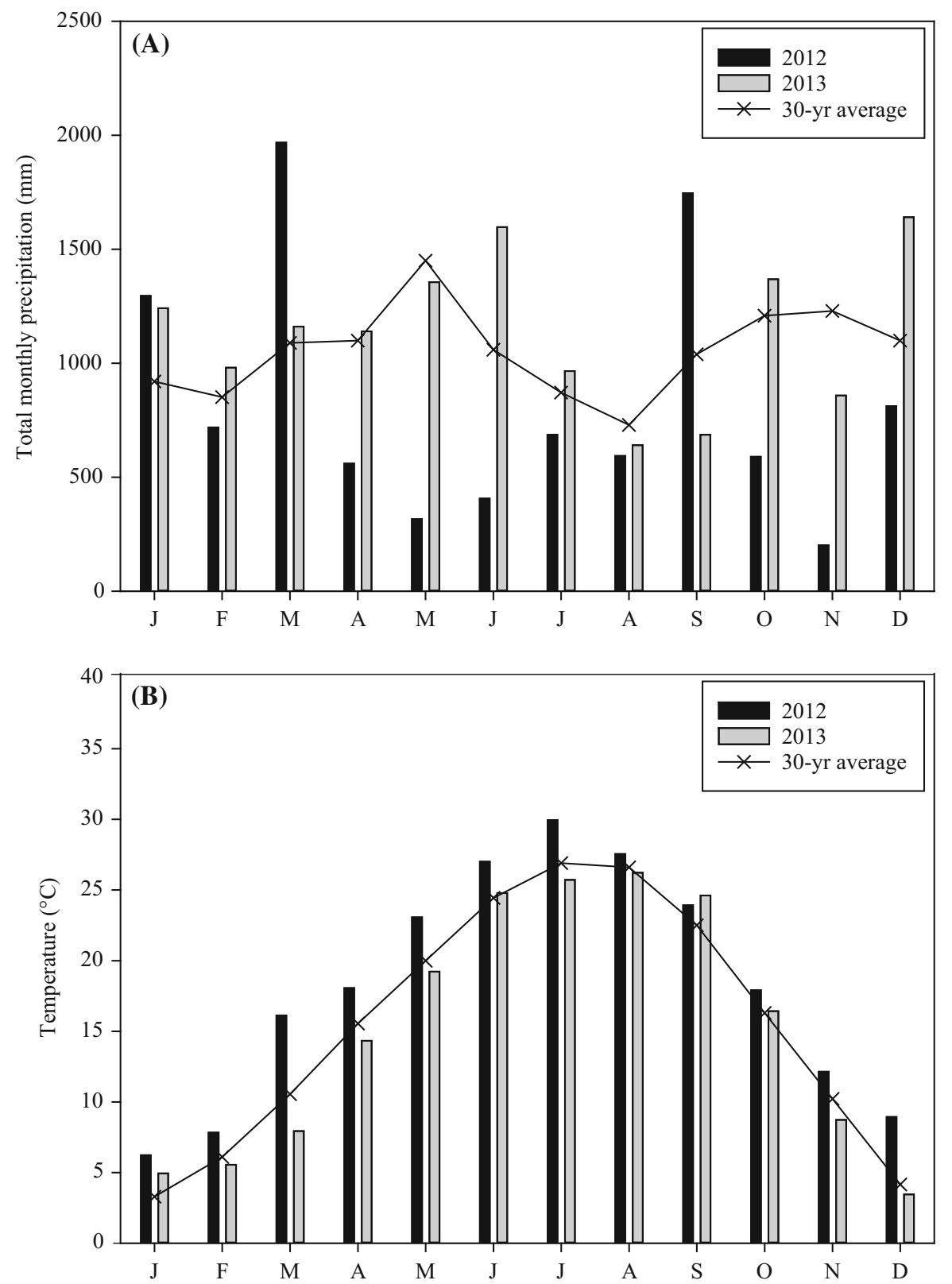

mean basal diameter of $2.3 \mathrm{~cm}$ were topped at $0.8 \mathrm{~m}$, dug intact to a rooting depth of about $15 \mathrm{~cm}$ with backhoe, and immediately transplanted to the pasture maintaining row to row distance of $3.0 \mathrm{~m}$ and plant to plant distance of $3.6 \mathrm{~m}$. Sericea lespedeza had been established at the site previously. Chemical weed suppressors, fertilizer, and soil amendments were not applied during the entire study period to evaluate their productivity. Alleys between the rows of all three species were mowed in 2012 and 2013.

\section{Data collection}

Samples were collected in June, July, August and September in 2012 and 2013. Three, 0.43 ha plot (1 plot/species) were used for the study. Each plot were divided equally into four blocks. Plant height (from the soil surface) and basal shoot diameter (at $5 \mathrm{~cm}$ above the ground) of four plants per block were measured and all plants in each block were counted. Plant biomass yield was determined by clipping tissue 
inside $1-\mathrm{m}^{2}$ quadrat at $5 \mathrm{~cm}$ stubble height for bristly locust and smooth sumac, and $0.25-\mathrm{m}^{2}$ quadrat at $2.5 \mathrm{~cm}$ above ground for sericea lespedeza. Harvested plants were separated into foliage (petioles plus leaflets) and woody shoots for foliage percentage (total foliage weight/total shoot weight $\times 100$ ) determination. Foliar and shoot samples were weighed, dried in a forced draft oven (Wisconsin Oven Corporation, East Troy, WI) for $48-72 \mathrm{~h}$ at $55^{\circ} \mathrm{C}$ and reweighed. Foliar samples were then ground in a Wiley mill (Thomas Scientific, Swedesboro, NJ) through a 2-mm sieve.

Foliage nitrogen $(\mathrm{N})$ and carbon $(\mathrm{C})$ content were measured using a $\mathrm{CN}$ analyzer (Vario MAX $\mathrm{CN}$; Elementar Analysensysteme GmbH, Germany) at the Agriculture Diagnostic Laboratory, University of Arkansas, Fayetteville, Arkansas. Foliage C:N ratio was calculated from the total $\mathrm{C}$ and $\mathrm{N}$ content. Crude protein was calculated by multiplying $\mathrm{N}$ content by 6.25. Acid detergent fiber (ADF) and acid detergent lignin (ADL) concentrations were determined using an Ankom 200 Fiber Analyzer (Ankom Technologies, Macedon, NY) following method developed by Vogel et al. (1999). Sodium sulfite was added to avoid CT precipitating protein in ADF and ADL (method 973; AOAC 2006). Condensed tannins were measured as protein-precipitable phenolics (PPP) by the Cooper et al. (2018) method, using purified species specific CT as standards for each species.

Statistical methods

Experimental design was a randomized complete block design with four replications per treatment. Fixed effects were plant species (bristly locust, smooth sumac, and sericea lespedeza) and sampling date (June, July, August, and September), with interactions being determined for plant nutritional composition, condensed tannin concentration, plant yield, height, and diameter. Each plot was randomly assigned a sampling date and repeatedly sampled. In all models, species (whole block) and harvest time (split-plot) were the fixed effects and year and replications were entered as random effects using PROC MIXED (SAS V9.3; SAS Inst. Cary, NC). All ANOVA assumptions of normally-distributed residuals (Shapiro-Wilk test) and homogeneity of variances (Levene's $F$-test) were confirmed. When significant differences were found $(P<0.05)$, pairwise post hoc comparisons of the least squares means were conducted using Least Significant Difference (LSD) at $P \leq 0.05$. Mean separations were performed by the SAS macro 'pdmix800' (Saxton 1998) with Fisher's Type-I error rate of 5\%.

Two models were analyzed, one with and one without repeated measures. Initially, dependent variables [yield and forage nutritive value (i.e., CP, C:N, $\mathrm{ADF}, \mathrm{ADL}$, and $\mathrm{CT}$ ) were analyzed using repeated measures ANOVA, PROC MIXED (SAS V9.3; SAS Inst. Cary, NC) over the 2-year study, with replicate and year being random effects, and sampling period being the repeated measures. For the repeated measure, an autoregressive covariance was used and the denominator degrees of freedom for the Type III F-test were adjusted with the Kenward-Roger method (Gomez et al. 2005). However, the -2 Loglikelihood did not change under the repeated-measure analysis (did not drop by at least 5 per covariance parameter) and the autoregressive correlation value (0.24) indicated a weak correlation among observations, so autoregressive covariance (repeated measures) was dropped. Thereafter, a second model (without repeated measures) was analyzed using a mixed model analysis of variance (MMAOV). Year was not significant; therefore, data were analyzed and presented across years.

\section{Results}

Foliar, shoot, and total aboveground biomass production

Sericea lespedeza was previously well established; however, survival rate for bristly locust and smooth sumac were about $50 \%$ from the 0 month to 1 year. Average foliar biomass yield from bristly locust, smooth sumac, and sericea lespedeza in this study from 2012 to 2013 were 2550, 3640, and $3400 \mathrm{~kg} \mathrm{DM} \mathrm{ha}^{-1}$ respectively. There was a species $\times$ harvest time interaction for foliar yield $(P=0.0125$; Table 1$)$ due to low leaf yield in bristly locust compared with sericea lespedeza and smooth sumac in June. In other months, foliar yield did not differ across species $(P>0.05$; Figs. 2 and 3$)$. Shoot biomass yield was similar across species $(P>0.05)$, but differed across months, in which yield was lowest during June compared to July, August, and September $(P<0.05)$. Total biomass (foliar and shoot) 
Table 1 Analysis of variance results for biomass and morphological characteristics of bristly locust (Robinia hispida), smooth sumac (Rhus glabra), and sericea lespedeza (Lespedeza cuneata) sampled in June, July, August and September in 2012 and 2013 in Booneville, Arkansas, USA

Num DF numerator degree of freedom, Den DF denominator degree of freedom, Foliar (\%) ratio of foliar to shoot mass

Fig. 2 Effect of species (bristly locust, smooth sumac, and sericea lespedeza) on monthly mean foliar, shoot, and aboveground total biomass yield during the growing season in 2012 and 2013 in

Booneville, Arkansas, USA. Standard error bars with different letters are significantly different for each biomass component (post-hoc test; $P<0.05$ )

\begin{tabular}{|c|c|c|c|c|}
\hline Fixed effect & Num DF & Den DF & F value & $\operatorname{Pr}>\mathrm{F}$ \\
\hline \multicolumn{5}{|l|}{ Foliar yield } \\
\hline Species & 2 & 69 & 17.96 & $<0.0001$ \\
\hline Harvest time & 3 & 69 & 18.64 & $<0.0001$ \\
\hline Species $\times$ harvest time & 6 & 69 & 2.96 & 0.0125 \\
\hline \multicolumn{5}{|l|}{ Shoot yield } \\
\hline Species & 2 & 69 & 0.36 & 0.7019 \\
\hline Harvest time & 3 & 69 & 9.08 & 0.0001 \\
\hline Species $\times$ harvest time & 6 & 69 & 0.39 & 0.8810 \\
\hline \multicolumn{5}{|l|}{ Total biomass } \\
\hline Species & 2 & 69 & 5.93 & 0.4144 \\
\hline Harvest time & 3 & 69 & 3.93 & 0.0002 \\
\hline Species $\times$ harvest time & 6 & 69 & 1.20 & 0.8145 \\
\hline \multicolumn{5}{|l|}{ Plant height } \\
\hline Species & 2 & 69 & 18.60 & $<0.0001$ \\
\hline Harvest time & 3 & 69 & 8.93 & $<0.0001$ \\
\hline Species $\times$ harvest time & 6 & 69 & 2.28 & 0.0458 \\
\hline \multicolumn{5}{|l|}{ Shoot diameter } \\
\hline Species & 2 & 69 & 185.89 & $<0.0001$ \\
\hline Harvest time & 3 & 69 & 10.55 & $<0.0001$ \\
\hline Species $\times$ harvest time & 6 & 69 & 0.73 & 0.6294 \\
\hline \multicolumn{5}{|l|}{ Foliar (\%) } \\
\hline Species & 2 & 69 & 17.96 & $<0.0001$ \\
\hline Harvest time & 3 & 69 & 18.64 & $<0.0001$ \\
\hline Species $\times$ harvest time & 6 & 69 & 2.96 & 0.0125 \\
\hline
\end{tabular}

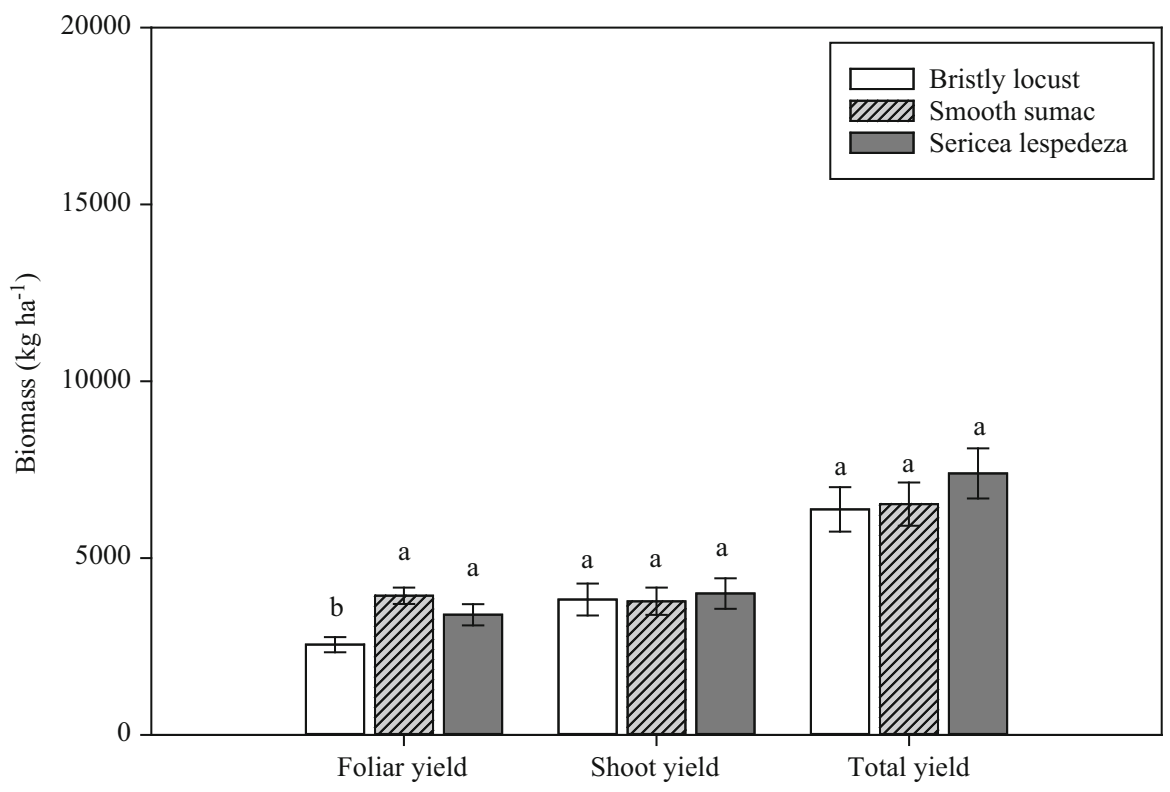



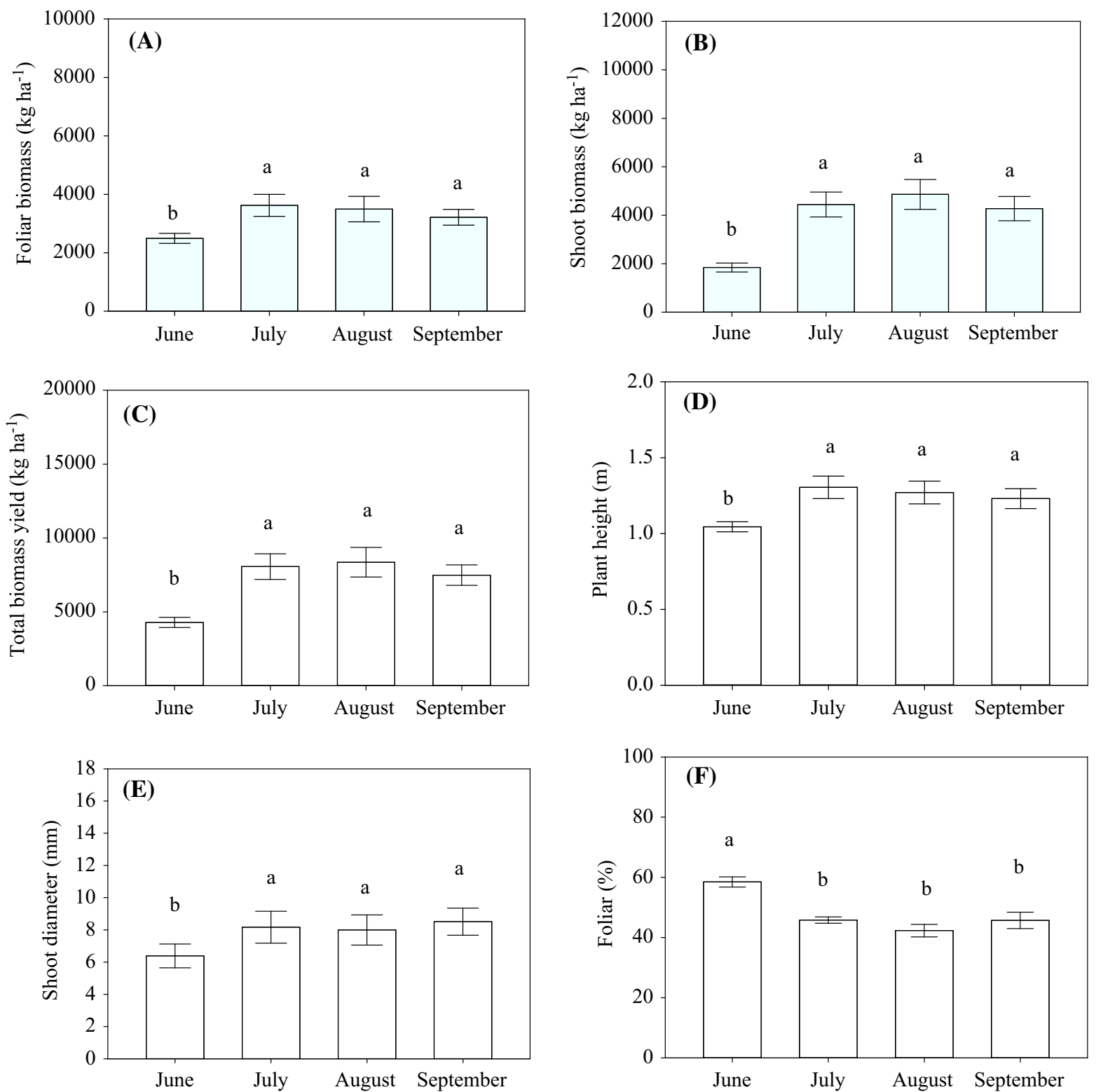

Fig. 3 Effect of harvest date on monthly mean A foliar yield, B shoot yield, C total above-ground biomass yield, D plant height, $\mathbf{E}$ basal shoot diameter, and $\mathbf{F}$ foliar percentage of three

production was similar for all species $(P=0.414)$; however, production differed across months $(P<0.05)$. In June, total biomass production was lower compared with July, August, and September $(P<0.05)$.

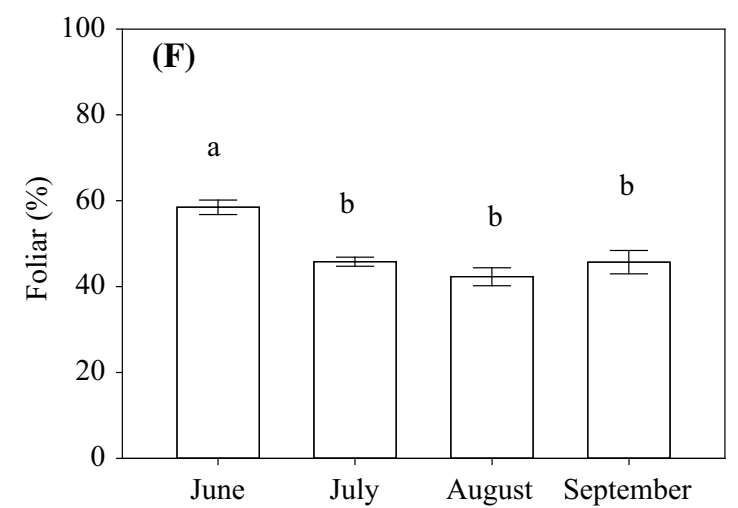

species throughout the growing season in 2012 and 2013 in Booneville, Arkansas, USA. Standard error bars with different letters are significantly different (post-hoc test; $P<0.05$ )

Foliar nutritive value

There was no interaction between species and harvest time for $\mathrm{CP}(P>0.05$; Table 2$)$. In all months, bristly locust had the greatest $\mathrm{CP}$ followed by sericea lespedeza and smooth sumac respectively $(P<0.05$; Fig. 4). The $\mathrm{C}: \mathrm{N}$ ratio differed among browse species. 
Table 2 Analysis of variance results for foliar nutritive value of bristly locust (Robinia hispida), smooth sumac (Rhus glabra), and sericea lespedeza (Lespedeza cuneata) sampled in June, July, August and September in 2012 and 2013 in Booneville, Arkansas, USA

Num DF numerator degree of freedom, Den DF denominator degree of freedom, $C P$ crude protein, $C: N$ carbon to nitrogen ratio, $A D F$ acid detergent fiber, $A D L$ acid detergent lignin, $C T$ condensed tannin

\begin{tabular}{|c|c|c|c|c|}
\hline Fixed effect & Num DF & Den DF & F value & $\operatorname{Pr}>\mathrm{F}$ \\
\hline \multicolumn{5}{|l|}{$\mathrm{CP}$} \\
\hline Species & 2 & 59 & 52.21 & $<0.0001$ \\
\hline Harvest time & 3 & 59 & 0.32 & 0.8143 \\
\hline Species $\times$ harvest time & 6 & 59 & 2.12 & 0.0644 \\
\hline \multicolumn{5}{|l|}{$\mathrm{C}: \mathrm{N}$} \\
\hline Species & 2 & 59 & 52.41 & $<0.0001$ \\
\hline Harvest time & 3 & 59 & 0.28 & 0.8405 \\
\hline Species $\times$ harvest time & 6 & 59 & 1.62 & 0.1568 \\
\hline \multicolumn{5}{|l|}{$\mathrm{ADF}$} \\
\hline Species & 2 & 66 & 80.67 & $<0.0001$ \\
\hline Harvest time & 3 & 66 & 1.58 & 0.2029 \\
\hline Species $\times$ harvest time & 6 & 66 & 1.86 & 0.1011 \\
\hline \multicolumn{5}{|l|}{ ADL } \\
\hline Species & 2 & 66 & 125.56 & $<0.0001$ \\
\hline Harvest time & 3 & 66 & 1.41 & 0.2480 \\
\hline Species $\times$ harvest time & 6 & 66 & 2.29 & 0.0455 \\
\hline \multicolumn{5}{|l|}{$\mathrm{CT}$} \\
\hline Species & 2 & 66 & 630.29 & $<0.0001$ \\
\hline Harvest time & 3 & 66 & 5.52 & 0.0019 \\
\hline Species $\times$ harvest time & 6 & 66 & 8.41 & $<0.0001$ \\
\hline
\end{tabular}

The C:N ratio was greatest in smooth sumac, was intermediate in sericea lespedeza, and lowest in bristly locust $(P<0.05)$. The $\mathrm{C}: \mathrm{N}$ ratio and ADF did not differ across months $(P>0.05)$; however, ADF differed among species $(P<0.05)$. Acid detergent fiber was similar between bristly locust and sericea lespedeza, $38.5 \%$ and $38.4 \%$, but was different for smooth sumac $(22.1 \% ; P<0.05)$. There was a species $\times$ harvest time interaction on ADL $(P<0.05)$. Acid detergent lignin was similar between bristly locust $(24.1 \%)$, and sericea lespedeza $(23.1 \%)$ but lower in smooth sumac $(6.3 \%)$ due to lower ADL during July and August $(P<0.05)$.

Finally, a species $\times$ harvest time interaction occurred with CT $(P<0.05)$, wherein $\mathrm{CT}$ was greatest in smooth sumac $\left(213 \mathrm{mg} \mathrm{CT}^{-1}\right)$ due to its high CT concentrations during June, intermediate in bristly locust ( $87 \mathrm{mg} \mathrm{CT}^{-1}$ ), and lowest in sericea lespedeza (41 $\mathrm{mg} \mathrm{CT}^{-1} ; P<0.05$ ).

Plant height, shoot basal diameter, and foliar percentage

Bristly locust and sericea lespedeza heights were 1.16 and $0.92 \mathrm{~m}$ respectively in June and remained constant until September; however, smooth sumac was tallest in July $(1.6 \mathrm{~m})$.

There was a species $\times$ harvest time interaction for plant height $(P<0.05$; Table 1$)$ due to differences occurring during July. In July, smooth sumac was tallest, bristly locust was intermediate, and sericea lespedeza was shortest $(P<0.05)$. Smooth sumac had the largest shoot diameter followed by bristly locust and sericea lespedeza $(P<0.05)$. Shoot diameter was smallest during June $(P<0.05$; Fig. 3$)$ and did not differ during July, August and September $(P>0.05)$. A species $\times$ harvest time interaction for foliar percentage occurred (Table 1). In June, smooth sumac had greater foliar percentage than bristly locust and sericea lespedeza $(P<0.05)$. All species had similar foliar percentage in July $(P>0.05)$. In August, smooth sumac and sericea lespedeza had similar but greater foliar percentage than bristly locust $(P<0.05)$. Smooth sumac had the greatest foliar percentage in September followed by sericea lespedeza and smooth sumac $(P<0.05)$. 

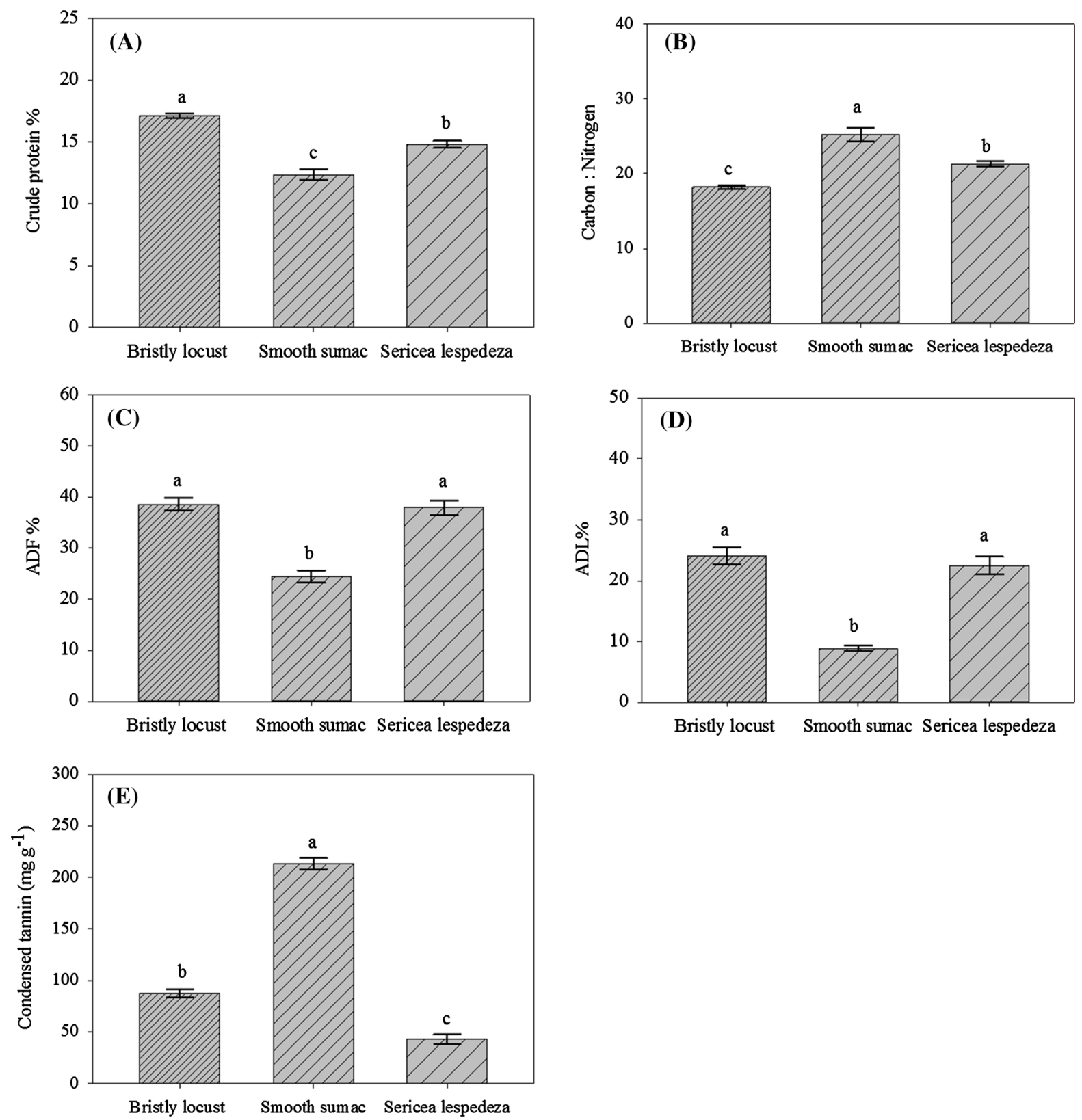

Fig. 4 Effect of species (bristly locust, smooth sumac, and sericea lespedeza) on A crude protein, $\mathbf{B}$ carbon:nitrogen ratio, $\mathbf{C}$ acid detergent fiber (ADF), D acid detergent lignin (ADL), and $\mathbf{E}$ condensed tannin throughout the growing season in 2012

\section{Discussion}

The southeastern U.S. often has hot, dry conditions during July and August (NOAA 2010) that cause predominant forage species (tall fescue and bermudagrass) to be semi-dormant (Burner et al. 2005), and of

and 2013 in Booneville, Arkansas, USA. Standard error bars with different letters are significantly different (post-hoc test; $P<0.05)$

low nutritional value; thus, alternative forage production is needed during this time. Bristly locust, smooth sumac, and sericea lespedeza grow well in the southeastern U.S. during summer (Bauni 1993; Ball and Mosjidis 2007; USDA NRCS 2018), due to their ability to tolerate high temperatures and low soil 
moisture (Mkhatshwa and Hoveland 1991; Bauni 1993; Burner and Burke 2012). Bristly locust, and sericea lespedeza are consumed by both sheep and goats, and goats highly prefer smooth sumac leaves (Bauni 1993; Min et al. 2004; Burner and Burke 2012). Average foliar biomass yield from bristly locust, sericea lespedeza, and smooth sumac in this study far exceeded tall fescue and bermudagrass yield (1000 kg DM ha ${ }^{-1}$ ) during August (Baker 2000; Burke et al. 2004). Thus, all three species could ameliorate forage deficiency during humid summers in the southeast for small ruminants in agroforestry systems.

Crude protein is essential for animal growth and development. Mature does requires 7\% $\mathrm{CP}$ for maintenance (NRC 2007); however, 12-17\% CP is required during growth, pregnancy, and lactation (NRC 2007). In this study bristly locust and sericea lespedeza met or exceeded normal CP requirement for lactating does and growing kids, but smooth sumac leaves contained nutritionally marginal levels of CP. Crude protein percentage of all plant species in the current study is consistent with other studies (Burner and Burke 2012; Hart 2013; Mechineni et al. 2014). Tall fescue and bermudagrass mixed pasture during summer from a nearby location contained $13 \% \mathrm{CP}$ (Acharya et al. 2015). Thus, all three species can provide similar or greater $\mathrm{CP}$ than tall fescue and bermudagrass mixed forage during summer months.

Acid detergent fiber is a nutritive entity that is least digestible by livestock and thus lower values are desirable (Beauchemin 1986). Acid detergent fiber of sericea lespedeza in this study is consistent with other studies (Lemus 2013). However, smooth sumac had greater ADF in this study than reported previously (Hart 2013). Acid detergent fiber of tall fescue and bermudagrass mixed forage from a nearby research site during summer 2013 was 28-36\% (Acharya et al. 2015). Thus, all three-plant species in the current study had similar or higher ADF compared with bermudagrass and tall fescue.

Alternatively, ADL, a measure of lignin content of forage, can be used to estimate energy content of forages (Waldo et al. 1972; Van Soest 1982). Forages with high ADL have low digestible energy and vice versa. Based on ADL value, smooth sumac was the most digestible of the three forage species.

Condensed tannins are the most widely studied plant secondary metabolites. Feeding CT-containing forages decreased gastrointestinal nematodes, specifically Haemonchus contortus in goats, (Min et al. 2004) and reduced coccidiosis in lambs (Burke et al. 2013). Additional advantages of feeding CT-rich forages include bloat prevention (Beddows 1956), increased animal live weight (Waghorn et al. 1999), improvement of lambing percentage (Min et al. 1999), and decreased fly strikes (Leathwick and Atkinson 1995). Forages containing CT concentrations of $50 \mathrm{mg} \mathrm{g}^{-1} \mathrm{DM}$ or less are not known to induce negative effects to ruminants, but higher than $60 \mathrm{mg} \mathrm{g}^{-1} \mathrm{DM}$ decreased forage intake (Barry and McNabb 1999; Bhatta et al. 2002). An additional disadvantage of high $\mathrm{CT}$ concentrations in forages includes decreased protein utilization (Donnelly and Wear 1972), decreased hemicellulose and readily fermentable carbohydrates (Barry and Manley 1984), and reduced mineral absorption (Scharenberg et al. 2007; Acharya et al. 2016). Negative effects of high CT containing forages varies with ruminant species. Goats and deer secrete proline-rich protein in their saliva that minimizes absorption of tannins and reduces their toxicity (Austin et al. 1989). In the current study, lower concentration of CT in sericea lespedeza (41 $\left.\mathrm{mg} \mathrm{g}^{-1} \mathrm{DM}\right)$ would not be expected to cause negative effect in animals. Bristly locust and smooth sumac had 87 and $213 \mathrm{mg} \mathrm{CT} \mathrm{g}^{-1}$, respectively, thus care should be taken while feeding these forages.

Height of sericea lespedeza in this current study is consistent with other studies (Swearingen and Bargeron 2016; Burner and Burke 2012). In contrast, smooth sumac and bristly locust were shorter than that reported in other studies, (USDA NRCS 2018; Burner and Burke 2012), which is reasonable as the plants in this study at the initiation had been transplanted less than a year earlier and were mowed before the growing season, whereas in other studies plants were more than 2 years old. In addition, plant height depends on factors such as soil type, fertility, topography, and soil moisture.

Sericea lespedeza basal shoot diameter is consistent with other studies (Sidhu 2010); however, bristly locust and smooth sumac had smaller diameters than reported by other authors (Burner and Burke 2012; Francis 2018). Plant age, soil moisture, and soil fertility could have impacted such differences. Browse species with high foliar percentage likely conduce large animal bites without obstruction (Koerth and 
Stuth 1991). In the current study, smooth sumac had the highest leaf percentage, followed by sericea lespedeza and bristly locust, respectively. Ruminants prefer a diet containing more leaf than stem (Arnold 1981); thus, based on relative abundance of foliage, sericea lespedeza and smooth sumac may be more preferred than bristly locust. However, this cannot be generalized as other factors such as palatability, accessibility, CT concentration, plant growth stage, and animal species play a role in forage consumption (Sanon et al. 2007).

\section{Conclusion}

Bristly locust, sericea lespedeza, and smooth sumac established and thrived in the southeastern environment. Foliar biomass and foliar nutritive value of all three species were similar or better compared with the dominant forage species in the region (tall fescue and bermudagrass). Among the three browse species, smooth sumac had highest mean foliar yield and, foliar percentage, and lowest ADF and ADL of all three species. However, smooth sumac had the lowest $\mathrm{CP}$ and highest CT. Condensed tannins at a low concentration are beneficial for ruminants, but when present in high concentrations decrease forage palatability and digestibility. Besides this, livestock species differ in CP requirement and ability to tolerate CT. Further studies are needed to compare the percentage utilization of these browse species by small ruminants.

Acknowledgements USDA is an equal opportunity provider and employer. Mentioned trade names or commercial products in this article is solely for the purpose of providing specific information and does not imply recommendation or endorsement by the USDA. The author gratefully acknowledge Tylor Cass Adams for his reviews and suggestions on earlier version of this manuscript. The technical assistance of Karen Chapman and Brent Woolley is greatly acknowledged.

Open Access This article is licensed under a Creative Commons Attribution 4.0 International License, which permits use, sharing, adaptation, distribution and reproduction in any medium or format, as long as you give appropriate credit to the original author(s) and the source, provide a link to the Creative Commons licence, and indicate if changes were made. The images or other third party material in this article are included in the article's Creative Commons licence, unless indicated otherwise in a credit line to the material. If material is not included in the article's Creative Commons licence and your intended use is not permitted by statutory regulation or exceeds the permitted use, you will need to obtain permission directly from the copyright holder. To view a copy of this licence, visit http://creativecommons.org/licenses/by/4.0/.

\section{References}

Acharya M, Burke JM, Coffey KP et al (2015) Changes in hematology, serum biochemistry, and gastrointestinal nematode infection in lambs fed sericea lespedeza with or without dietary sodium molybdate. J Anim Sci 93:1952-1961

Acharya M, Burke JM, Coffey KP et al (2016) Changes in concentrations of trace minerals in lambs fed sericea lespedeza leaf meal pellets with or without dietary sodium molybdate. J Anim Sci 94:1592-1599

Adams MA, Simon J, Pfautsch S (2010) Woody legumes: a (re)view from the South. Tree Physiol 30:1072-1082

AOAC (2006) Official methods of analysis of AOAC, 18th edn. AOAC Int, Arlington, VA

Arnold GW (1981) Grazing behavior. In: Morley FHW (ed) Grazing animals. Elsevier, Amsterdam, pp 79-104

Austin PJ, Suchar LA, Robbins CT et al (1989) Tannin-binding proteins in saliva of deer and their absence in saliva of sheep and cattle. J Chem Ecol 15:1335-1347

Baker JL (2000) 1999 Forage yields from bermudagrass varieties and strains. Noble Found. Inc, Ardmore, Oklahoma, USA

Ball D, Mosjidis J (2007) Sericea lespedeza: a pasture, hay and conservation plant. ANR-1318, Alabama Cooperative Extension System (Alabama A \& M University and Auburn University). http://www.aces.edu/pubs/docs/A/ ANR-1318/ANR-1318.pdf. Accessed 18 March 2018

Ball DM, Hoveland CS, Lacefield GD (2015) Southern forages, modern concept for forage crop management, 5th edn. International Plant Nutrition Institute, Norcross, GA

Barry TN, Manley TR (1984) The role of condensed tannins in the nutritional value of Lotus pedunculatus for sheep. 2. Quantitative digestion of carbohydrates and proteins. Br J Nutr 51:493-504

Barry TN, McNabb WC (1999) The implication of condensed tannins on the nutrition value of temperate forages fed to ruminants. Br J Nutr 81:263-272

Bauni SM (1993) Utilization of cross timbers rangelands by Angora goat. Ph.D. dissertation. Oklahoma State University, Stillwater, OK

Beauchemin KA (1986) Using ADF and NDF in dairy cattle diet formulation-a western Canadian perspective. Anim Feed Sci Techol 58:101-111

Beddows AR (1956) Observation on hoove, haven, blown or bloat taken from agriculture writing. J Agric Soc Univ Coll Wales 33:12-15

Bhatta R, Shinde AK, Vaithiyanathan S et al (2002) Effect of polyethylene glycol-6000 on nutrient intake, digestion and growth of kids browsing prosopis cineraria. Anim Feed Sci Technol 101:45-54

Burke JM, Miller JE, Terrill TH et al (2013) Sericea lespedeza as an aid in the control of Eimeria spp. In lambs. Vet Parasitol 193:39-46 
Burke JM, Brauer DK, Looper ML (2004) Use of novel endophyte-infected tall fescue for cow-calf production in Arkansas. J Anim Sci 82 (Suppl 1):91

Burner DM, Burke JM (2012) Survival of bristly locust (Robinia hispida L.) in an emulated silvopasture. Native Plants 13:195-200

Burner DM, Pote DH, Ares A (2005) Management effects on biomass and foliar nutritive value of Robinia pseudoacacia and Gleditsia triacanthos f. inermis in Arkansas, USA. Agrofor Syst 65:207-2014

Clarke ID, Rodgers JS, Sievers AF et al (1949) Tannin content and other characteristics of native sumac in relation to its value as a commercial source of tannin. US Dep Agric Tech Bull No 986. Washington DC, p 76

Cooper CE, Muir JP, Morgan CLS et al (2018) Tortoise or hare: will resprouting oaks or reseeding pines dominate following severe wildlife? Forest Ecol Manag 408:54-66

Donnelly ED, Wear JI (1972) Acid detergent method for reduction of tannin interference in determining lignin of sericea lespedeza. Agron J 64:838-839

Fernald ML (1950) Gray's manual of botany, 8th edn. American Book Company, New York

Francis JK (2018) Rhus glabra L. ANACARDIACEAE. http:// citeseerx.ist.psu.edu/viewdoc/download?rep=rep1\&type= pdf\&doi=10.1.1.214.319. Accessed 24 March 2018

Gomez EV, Schaalje GB, Fellingham GW (2005) Performance of the Kenward-Roger method when the covariance structure is selected using AIC and BIC. Commun Stat Simul 34:377-392

Hart S (2013) Identification and management of different browse species adapted to the southern region. In: Karki U (ed) Sustainable year-round forage production and grazing/ browsing management for goats in the Southern regions. Handbook for training field extension and technical assistance personnel. Tuskegee University Cooperative Extension System, Tuskegee, pp 70-80

Hensley DL, Carpenter PL (1986) Survival and coverage by several $\mathrm{N}_{2}$ fixing trees and shrubs on lime-amended acid mine spoil. Tree Planters' Notes 37:27-31

Karki U (2013) Forage identification and classification. In: Karki U (ed) Sustainable year-round forage production and grazing/browsing management for goats in the Southern regions. Handbook for training field extension and technical assistance personnel. Tuskegee University Cooperative Extension System, Tuskegee, pp 13-63

Koerth BH, Stuth JW (1991) Instantaneous intake rates of 9 browse species by white tailed deer. J Range Manag 44:614-618

Leathwick DM, Atkinson DS (1995) Dagginess and flystrike in lambs grazing on Lotus corniculatus or rgegrass. Proc N Z Soc Anim Prod 55:196-198

Lemus R (2013) Basic agronomic and physiological principles of forage production. In: Karki U (ed) Sustainable yearround forage production and grazing/browsing management for goats in the Southern regions. Handbook for training field extension and technical assistance personnel. Tuskegee University Cooperative Extension System, Tuskegee, pp 13-63

Mechineni A, Kommuru DS, Gujja S et al (2014) Effect of fallgrazed sericea lespedeza (Lespedeza cuneata) on gastrointestinal nematode infections of growing goats. Vet Parasitol 204:221-228

Min BR, McNabb WC, Barry TN et al (1999) The effect of condensed tannins in Lotus corniculatus upon reproductive efficacy and wool production in sheep during late summer and autumn. J Agric Sci Camb 132:323-334

Min BR, Pomroy WE, Hart SP et al (2004) The effect of shortterm consumption of a forage containing condensed tannins on gastro-intestinal nematode prarasite infection in grazing wether goats. Small Rumin Res 51:279-283

Mkhatshwa PD, Hoveland CS (1991) Sericea lespedeza production on acid soils in Swaziland. Trop Grasslands 25:337-341

Molz FJ, Browning VD (1977) Effect of vegetation on landfill stabilization. Ground Water 15:409-415

National Oceanic and Atmospheric Administration (NOAA) (2010) Climatography of the United States, annual and seasonal normals of temperature and precipitation 1981-2010: Booneville, Arkansas. United States Department of Commerce, National Climatic Data Center, Ashville

National Research Council (2007) Nutrition requirement of small ruminants. National Academy Press, Washington, DC

Natural Resource Conservation Services (NRCS) (2003) Soil Survey. Leadvale series. https://soilseries.sc.egov.usda. gov/OSD_Docs/L/LEADVALE.html. Accessed 5 Feb 2018

Rayne S, Mazza G (2007) Biological activities of extracts from sumac (Rhus spp.): a review. Plant Foods Hum Nutr 62:165-175

Sanon HO, Kabore-Zoungrana C, Ledin I (2007) Behaviour of goats, sheep and cattle and their selection of browse species on natural pasture in a Sahelian area. Small Rumin Res 67:64-74

Saxton AM (1998) A macro for converting mean separation output to letter groupings in Proc Mixed. In: Proceedings of 23rd SAS users Group Intl, SAS Institute, Cary, NC, pp 1243-1246

Scharenberg A, Arrigo Y, Gutzwiller A et al (2007) Effect of feeding dehydrated and ensiled tanniferous sainfoin (Onobrychis viciifolia) on nitrogen and mineral digestion and metabolism of lambs. Arch Anim Nutr 61:390-405

Sidhu G (2010) Variability for morphological and forage quality traits in sericea lespedeza (Lespedeza cuneate (Dumont de Courset) G. Don) cultivars. Master thesis. Auburn University, Auburn, Alabama

Swearingen J, Bargeron C (2016) Invasive plant atlas of the United States. University of Georgia Center for Invasive Species and Ecosystem Health. http://www. invasiveplantatlas.org/. Accessed 5 Feb 2018

Terrill TH, Miller JE, Burke JM et al (2012) Experience with integrated concepts for the control of Haemonchus contortus in sheep and goats in the United States. Vet Parasitol 186:28-37

USDA Natural Resources Conservation Service (2018) The plant database. https://plants.usda.gov/factsheet/pdf/fs rohif8.pdf. Accessed 21 March 2018

Van Soest PJ (1982) Nutritional ecology of the ruminant. O and B Books Inc., Corvalis, Oregon, USA 
Vogel KP, Pedersen JF, Masterson SD, Toy JJ (1999) Evaluation of a filter bag system for NDF, ADF, and IVDMD forage analysis. Crop Sci 39:276-279

Waghorn GC, Reed JD, Ndlovu LR (1999) Condensed tannins and herbivore nutrition. Proc XVIIth Int Grassl Congr 3:153-156

Waldo DR, Smith LW, Cox EL (1972) Model of cellulose disappearance from the rumen. J Dairy Sci 55:125-129
Publisher's Note Springer Nature remains neutral with regard to jurisdictional claims in published maps and institutional affiliations. 